\title{
Effect of Different Inoculum Combination on Biohydrogen Production from Melon Fruit Waste
}

\author{
Yumechris Amekanª, Dyah Sekar Ayu Pudak Wangia, Muhammad Nur Cahyantob, Sartoc," \\ and Jaka Widada ${ }^{\mathrm{d}}$
}

\author{
${ }^{a}$ Department of Biotechnology, Gadjah Mada University, Yogyakarta, Indonesia, 55281 \\ ${ }^{b}$ Department of Food and Agricultural Product Technology, Faculty of Agricultural Technology, Gadjah Mada University, Yogyakarta, \\ Indonesia, 55281
}

${ }^{*}$ "Department of Chemical Engineering, Gadjah Mada University, Yogyakarta, Indonesia, 55281

${ }^{d}$ Department Agriculture Microbiology, Gadjah Mada University, Yogyakarta, Indonesia, 55281

\begin{abstract}
The natural microbial consortium from many sources widely used for hydrogen production. Type of substrate and operating conditions applied on the biodigesters of the natural consortium used as inoculum impact the variation of species and number of microbes that induce biogas formation, so this study examined the effect of different inoculum source and its combination of biohydrogen production performance. The hydrogen producing bacteria from fruit waste digester (FW), cow dung digester (CD), and tofu waste digester (TW) enriched under strictly anaerobic conditions at $37^{\circ} \mathrm{C}$. Inoculums from 3 different digesters (FW, CD, and TW) and its combination (FW-CD, CD-TW, FW-TW, and FW-CD-TW) were used to test the hydrogen production from melon waste with volatile solids (VS) concentration of $9.65 \mathrm{~g} / \mathrm{L}, 37^{\circ} \mathrm{C}$ and initial $\mathrm{pH} 7.05 \pm 0.05$. The results showed that individual and combined inoculum produced the gas comprising hydrogen and carbon dioxide without any detectable methane. The highest cumulative hydrogen production of $743 \mathrm{~mL}$ (yield $207.56 \mathrm{~mL} / \mathrm{gVS}$ ) and $1,132 \mathrm{~mL}$ (yield $231.02 \mathrm{~mL} / \mathrm{gVS}$ ) was shown by FW and FW-CD-TW, respectively. Butyric, acetate, formic and propionic were the primary soluble metabolites produced by all the cultures, and the result proves that higher production of propionic acid can decrease hydrogen yield. Clostridium perfringens and Clostridium baratii prominently seen in all single and combination inoculum. Experimental evidence suggests that the inoculum from different biodigesters able to adapt well to the environmental conditions and the new substrate after a combination process as a result of metabolic flexibility derived from the microbial diversity in the community to produce hydrogen. Therefore, inoculum combination could be used as a strategy to improve systems for on-farm energy recovery from animal and plant waste to processing of food and municipal waste.
\end{abstract}

Keywords: Inoculum; Biohydrogen; Melon fruit waste; Dark Fermentation; Denaturing Gradient Gel Electrophoresis

Article History: Received February $5^{\text {th }}$ 2018; Received in revised form May 7th 2018; Accepted June 2nd 2018; Available online

How to Cite This Article: Amekan, Y., Wangi, D.S.A.P., Cahyanto, M.N., Sarto and Widada, J. (2018) Effect of Different Inoculum Combination on Biohydrogen Production from Melon Fruit Waste. Int. Journal of Renewable Energy Development, 7(2), $101-109$.

https://doi.org/10.14710/ijred.7.2.101-109

\section{Introduction}

Currently, the high rate of economic and population growth led to an increase in fuel demand as the main energy source for industry, transportation, and even electricity generation. Concern about rapid depletion of fossil fuels and environmental pollution are stimulating studies on alternative energy sources to reduce dependence on fossil fuels (Das and Veziroglu, 2001). Hydrogen $\left(\mathrm{H}_{2}\right)$ is a potential energy carrier because it is renewable (Karthic and Joseph, 2012), clean (Sivagurunathan et al., 2016) and has a very high energy yield $(122 \mathrm{~kJ} / \mathrm{g})$. It is 2.75 times greater than fossil fuels (Hand and Shin, 2004; Kapdan and Kargi, 2006; Choi and Ahn, 2015). Hydrogen can be produced biologically and chemically (Sivagurunathan et al., 2016; Hand and Shin,
2004; Kumar et al., 2015). Biological hydrogen production through photosynthesis and fermentation are more environmentally friendly with lower energy requirements than chemical production processes (Kumar et al., 2015; Pachapur et al., 2015). Anaerobic fermentation is simpler because the process does not require light (Sivagurunathan et al., 2016; Hand and Shin, 2004) and it can apply to wide range of feedstocks (Nath and Das, 2004). Current research has studied various types of substrates for hydrogen production, such as glucose (Li et al., 2008), sucrose (Choi and Ahn, 2015), galactose (Sivagurunathan et al., 2016), cassava starch (Tien et al, 2016), the starch residue of sweet potato (Yokoi et al., 2001), sugarcane bagasse (Pattra et al., 2008) and extracts of pineapple wastes (Ruknongsaeng et al., 2005). The

\footnotetext{
* Corresponding author: sarto@chemeng.ugm.ac.id
} 
availability, cost, carbohydrate content and biodegradability are the important criteria for the substrate selection (Kapdan and Kargi, 2006; Cai, et al., 2009). In Indonesia, melon production reached 129,706 tons/year with the potential for waste generated $\pm 12,970$ tons/year. Melon waste containing lignin (8.26\%), hemicellulose $(22.71 \%)$, cellulose (19.01\%), soluble starch $(17.22 \%)$, total sugar $(30.42 \%)$, lipid $(6.91 \%)$, total $\mathrm{N}$ $(0.89 \%)$, total solids $(7.67 \%)$ and volatile solids $(6.45 \%)$. Cahyari et al. (2011) using melon fruit waste as a substrate for hydrogen production in batch at thermophilic conditions $\left(55^{\circ} \mathrm{C}\right)$ yield $5.96 \mathrm{mmole} \mathrm{H}_{2} / \mathrm{gVS}$, and the potential $\mathrm{H}_{2}$ production reached 185,808,197 $\mathrm{m} 3$ STP.

According to Reith et al. (2003), the formation of biogas (anaerobic digestion) induced by various types of microbes, usually obtained through a natural enrichment of each substrate used. The composition and amount of bacteria involved in this process will vary depending on the type of substrate and fermentation conditions were applied, causing the variation of yield and biogas production rate (Sivagurunathan et al., 2016; Pachapur et al., 2015; Insam et al., 2010). Sivagurunathan et al. (2014) conducted a study on the use of a combination of three different mixed cultures (cow dung, pig slurry, and sewage sludge) to increase hydrogen production using glucose as a substrate. The results showed an increase in hydrogen yield and production rate by mixed cultures of pig slurry+sewage sludge $\left(2.34\right.$ mole $\mathrm{H}_{2} /$ mole glucose and 6.76 $\mathrm{L} /$ day) compared to the single culture of pig slurry (1.59 mole $\mathrm{H}_{2} /$ mole glucose and $4.43 \mathrm{~L} /$ day). An understanding of the effect of an increase in the interaction between microbial diversity and the production of hydrogen is essential to form a stable hydrogen production process. Therefore, in the present study, we investigated the effect of inoculum from different biogas digesters (tofu waste, fruit waste and cow dung anaerobic digester) and their combinations to the biohydrogen production performance and soluble metabolites production using melon fruit waste as the substrate in the batch test.

\section{Materials and Methods}

\subsection{Inoculum and substrate preparation}

The seed sludge collected from fruit waste, cow dung and tofu waste biodigester in Yogyakarta (Indonesia), designated as FW, CD, and TW, respectively, for enriching the mixed cultures. All microbial sources were acidified to $\mathrm{pH} 3$ through the addition of $2 \mathrm{M} \mathrm{HCl}$ and maintaining for 24 hours, then adjusting back to $\mathrm{pH} 6.8$ with the addition of $2 \mathrm{M} \mathrm{NaOH}$ (Ren et al., 2008) to deactivate the hydrogenotrophic methanogens before use in the enrichment of hydrogen-producing bacteria using glucose as the sole carbon source. The melon fruit waste used in this study collected from Gemah Ripah fruit market located in Yogyakarta. The characteristics of the melon waste were: water $(92.30 \%)$, total solids $(7.71 \%)$, ash $(1.25 \%)$ and volatile solid (6.48\%). The melon slurry was stored at $4^{\circ} \mathrm{C}$ until used as the hydrogen fermentation substrate (Ruggeri and Tommasi, 2012).

\subsection{Enrichment of hydrogen-producing bacteria}

Enrichment of $\mathrm{H}_{2}$ producing bacteria was carried out in $100 \mathrm{~mL}$ serum vials with $50 \mathrm{~mL}$ working volume at $37^{\circ} \mathrm{C}$, following a method described elsewhere (Sivagurunathan et al., 2014). The sterile pre-reduced peptone-yeast extract-glucose (PYG) medium contains peptone $10 \mathrm{~g} / \mathrm{L}$, yeast extract $10 \mathrm{~g} / \mathrm{L}$, resazurin $0.001 \mathrm{~g} / \mathrm{L}$, L-cysteine-HCl0.5 g/L, glucose $10 \mathrm{~g} / \mathrm{L}$. The $\mathrm{pH}$ adjusted to 7.0 using either $1 \mathrm{~N} \mathrm{HCl}$ or $\mathrm{NaOH}$ before the autoclave. Three successive transfers in PYG medium with $0.05 \%$ cysteine- $\mathrm{HCl}$ were done to obtain the mixed-cultures $\mathrm{FW}$, $\mathrm{CD}$, and TW from fruit waste, cow dung, and tofu waste digester, respectively. Freshly grown (24 h) enriched mixed cultures used as the inoculum for all the fermentation experiments.

\subsection{Batch hydrogen fermentation}

A series of batch hydrogen fermentation tests were carried out to check the hydrogen production performance of individual and combined inoculum. Batch experiments were carried out in serum vials $(100 \mathrm{~mL})$ with $50 \mathrm{~mL}$ working volume under strict anaerobic condition. Five $\mathrm{mL}$ of enriched culture was added as the inoculum to the fermentation medium, following the method described by Sivagurunathan et al. (2014). The batch hydrogen fermentation of melon waste was carried out by the individual, and combined inoculum in basal medium contains volatile solid $9.65 \mathrm{~g} / \mathrm{L}, \mathrm{Na}_{2} \mathrm{HPO}_{4} 5 \mathrm{~g} / \mathrm{L}, \mathrm{KH}_{2} \mathrm{PO}_{4} 2$ $\mathrm{g} / \mathrm{L}, \mathrm{MgSO}_{4} \cdot 7 \mathrm{H}_{2} \mathrm{O} 0.50 \mathrm{~g} / \mathrm{L}$. The single inoculum was mixed in equal volumes to prepare the combined inoculum. All batch serum vials incubated in an incubator with temperature controlled at $37^{\circ} \mathrm{C}$. The initial cultivation $\mathrm{pH}$ was adjusted to 7.0 using either $1 \mathrm{~N} \mathrm{HCl}$ or $\mathrm{NaOH}$ before the autoclave. The volatile fatty acids (VFA) analysed for samples collected at the end of the fermentation. Fermentation was carried out until the cessation of gas production. All experiments were carried out in duplicates, and the mean \pm SD (standard deviation) reported.

\subsection{Analytical methods}

The volume of biogas was measured using an airtight glass syringe. The biogas composition $\left(\mathrm{H}_{2}, \mathrm{CH}_{4}\right.$, and $\left.\mathrm{CO}_{2}\right)$ analysed with a gas chromatograph having a thermal conductivity detector (GC-14B, Shimadzu, Japan). The analytical procedures of standard methods (APHA, 1998) were used to determine the $\mathrm{pH}$, and VS. Volatile fatty acids (VFA) were analysed using gas chromatograph having a flame ionisation detector (Hewlett Packard 5890 Series II).

\subsection{DNA extraction and PCR amplification}

Total DNA extracted from bacterial cell pellet of H2 fermentation using Wizard ${ }^{\circledR}$ Genomic DNA extraction kit. PCR was performed using $12.5 \mu \mathrm{L}$ Gotaq Green Master Mix, one $\mu \mathrm{l}$ of each primer $(10 \mu$ mole/L), one $\mu \mathrm{L}(10 \mathrm{ng} / \mu \mathrm{L})$ of template DNA, and $9.5 \mu \mathrm{L}$ of nuclease-free water to give a final volume of $25 \mu \mathrm{L}$. The first primer was amplified with 16S rDNA using 27f (5'GAGAGTTTGACTCTGGCTCAG-3') and 1495r (5'CTACGGCTACCTTGTTACGA-3'). Those primers are 
universal primer set (Liu et al., 2009). Bacterial 16S rDNA were amplified at a temperature of $95^{\circ} \mathrm{C}$ for $3 \mathrm{~min}$, followed by 30 cycles at $95^{\circ} \mathrm{C}-30 \mathrm{sec}, 55^{\circ} \mathrm{C}-30 \mathrm{sec}, 72^{\circ} \mathrm{C}-1$ min and the final extension at $72^{\circ} \mathrm{C}-5 \mathrm{~min}$. The second primers used for the PCR were EuB 984f with GC-clamps (5'CGCCCGGGGCGCGCCCCCGGCGGGGCGGGGGCAC GGGGGGAACGCGAACGCGAAGAACCTTAC-3') and EuB1398r (5'CGGTGTGTCCAAGGCCCGGGAACG-3') (Eurofins MWG Operon, Japan). The second primer target was $500 \mathrm{bp}$ reflecting a sequence of V6-8 region in $16 \mathrm{~S}$ rDNA. V6-8 regions were amplified using the following program; $95^{\circ} \mathrm{C}$ for $3 \mathrm{~min}$, followed by 34 cycles at $95^{\circ} \mathrm{C}$ for $15 \mathrm{sec}, 55^{\circ} \mathrm{C}$ for $30 \mathrm{sec}, 72^{\circ} \mathrm{C}$ for $30 \mathrm{sec}$ and the final extension at $72^{\circ} \mathrm{C}$ for $5 \mathrm{~min}$. The size of PCR product was confirmed by electrophoresis in $1.3 \%$ agarose gel in ethidium bromide solution.

\subsection{Analysis of Denaturing Gradient Gel Electrophoresis (DGGE) bands}

Digitized Denaturing Gradient Gel Electrophoresis (DGGE) images were also analysed using gel compare II software, version 6.6 (Applied Maths, Kortjnk, Belgium). This software carries out relative intensity value of each band to the total intensity of bands in all cultures. Shannon index was calculated using (Eq.1.) and (Eq.2.) as described below

$$
\begin{aligned}
& \mathrm{H}=-\sum_{\mathrm{i}=1}^{\mathrm{s}} \text { pi ln pi } \\
& \mathrm{EH}=\frac{\mathrm{H}}{\operatorname{Hmax}}=\mathrm{H} / \ln \mathrm{S}
\end{aligned}
$$

Where $\mathrm{H}$ is the value of the Shannon index, pi is the ratio of the specific band intensity to the total intensity of all bands. The Richness (S) of the bacterial community determined from the number of bands in each lane (Sun et al., 2015; Diez et al., 2001). Two matrices constructed; the first took into account intensity of individual bands related to intensities of the $\mathrm{FW}-\mathrm{CW} 7$ band (intensity matrix), whereas the second matrix (distance matrix) measure the distance between individual band to FW-CW 7 bands. The intensity matrix was used to calculate bacterial diversity. Both matrices were then used to construct a non-metric multidimensional scaling (NMDS) diagram. The diagram places each sample at a point in a plane (with dimensions of no special significance). A similar bacterial diversity index in inoculum combinations will plot together.

\subsection{Bacterial species identification}

Predominant Denaturing Gradient Gel Electrophoresis (DGGE) bands (1-16) were excised and eluted in $50 \mu \mathrm{L}$ of Mili-Q water at $4^{\circ} \mathrm{C}$ overnight. They were then were centrifuged at $11,000 \mathrm{xg}$ for $2 \mathrm{~min}$ using MX-105 refrigerated microcentrifuge (Tomy Seiko, Japan). The DNA concentration of the supernatant used as the template for the next PCR using the second primer without GC-clamps. PCR products were purified using the FastGene Gel/PCR extraction kit (Nippon genetics, Japan) and sequenced in DNA sequencer of Eurofins Company, Japan. Basic local alignment search tool (BLAST) used to evaluate the similarity sequence data of DGGE bands with 16S rDNA reference sequences at GenBank (http://www.ncbi.nlm.nih.gov). MEGA 6.0 software used for phylogenetic tree construction.

\section{Results and Discussion}

\subsection{Influence of origin of inoculum on hydrogen production from melon waste}

The anaerobic fermentation process includes four biochemical functions, namely hydrolysis, acidogenesis, acetogenesis, and methanogenesis. $\mathrm{H}_{2}$ products can obtain during the acidogenesis and acetogenesis stages, whereas methanogenesis used $\mathrm{H}_{2}$ as an electron donor and converted to methane $\left(\mathrm{CH}_{4}\right)$ (Mohan, 2009; Saady, 2013). Therefore, hydrogenotrophic methanogens should be inhibited or eliminated in the utilisation of anaerobic microflora for $\mathrm{H}_{2}$ fermentation (Hawkes et al., 2007). The inhibition did by acid treatment $(\mathrm{pH} 3 ; \pm 24 \mathrm{~h})$ against the seed sludge (Ren et al., 2008; Chang et al., 2011). The results prove that $\mathrm{H}_{2}$-producing inoculum from fruit waste (FW), cow dung (CD) and tofu waste (TW) digester are capable of producing gas consisting of hydrogen $(46-65 \%)$ and carbon dioxide (35-54\%). Methane was undetectable for seven days of fermentation (Table 1).

Table 1.

Hydrogen production from melon waste in batch fermenter by Single inoculum from fruit waste (FW), cow dung (CD), and tofu waste

\begin{tabular}{|c|c|c|c|c|c|c|}
\hline Inc. & Final pH & $\begin{array}{c}\text { Total gas* } \\
(\mathrm{mL} / \mathrm{L})\end{array}$ & $\begin{array}{c}\text { Total } \mathrm{CO}_{2}{ }^{*} \\
(\mathrm{~mL} / \mathrm{L})\end{array}$ & $\begin{array}{c}\text { Total } \mathrm{H}_{2}{ }^{*} \\
(\mathrm{~mL} / \mathrm{L})\end{array}$ & $\begin{array}{c}\text { Yield } \mathrm{H}_{2} \\
\text { (mL/g VS) }\end{array}$ & $\begin{array}{l}\text { Yield } \mathrm{CO}_{2} \\
\text { (mL/g VS) }\end{array}$ \\
\hline FW & $4.67 \pm 0.01$ & $1,254 \pm 28^{\mathrm{a}}$ & $511 \pm 4$ & $743 \pm 32^{\mathrm{d}}$ & $207.56 \pm 14.61^{\mathrm{f}}$ & $142.74 \pm 2.75$ \\
\hline $\mathrm{CD}$ & $4.66 \pm 0.04$ & $796 \pm 65^{b}$ & $369 \pm 29$ & $428 \pm 36^{\mathrm{e}}$ & $129.74 \pm 9.82^{\mathrm{g}}$ & $111.83 \pm 7.83$ \\
\hline TW & $4.64 \pm 0.01$ & $641 \pm 25^{\mathrm{c}}$ & $319 \pm 15$ & $323 \pm 40^{\mathrm{e}}$ & $92.39 \pm 12.41^{\mathrm{g}}$ & $91.17 \pm 3.39$ \\
\hline
\end{tabular}
(TW) digester $\left(37^{\circ} \mathrm{C}\right.$, start $\mathrm{pH} 7$, volatile solid $\left.9.65 \mathrm{~g} / \mathrm{L}\right)$.

Legend: ${ }^{*}=$ gas volume at the standard conditions $\left(1 \mathrm{~atm} .25^{\circ} \mathrm{C}\right)$; different letter in the same column indicate significant difference statistically at the 0.05 level

Inoculum from fruit waste digester produces the highest hydrogen $(743 \mathrm{~mL} / \mathrm{L}$; yield $207.56 \mathrm{~mL} / \mathrm{gVS})$ among the single inoculums. Sivagurunathan et al. [20] showed similar results using three different inoculums, i.e., cow dung $\left(2,139 \mathrm{~mL} \mathrm{H}_{2}\right)$, sewage sludge $\left(2,330 \mathrm{~mL} \mathrm{H}_{2}\right)$ and pig slurry $\left(1.633 \mathrm{~mL} \mathrm{H}_{2}\right)$. The result is supporting the notion that the difference in the performance of hydrogen production caused by the variation of species and number of microbes that induce anaerobic digestion which is affected by the type of substrate and operating conditions applied on the biodigesters of natural consortium used as inoculum (Akutsu et al., 2008). 
Citation: Amekan, Y., Wangi, D.S.A.P., Cahyanto, M.N., Sarto and Widada, J..(2018), Effect of Different Inoculum Combination on Biohydrogen Production from Melon Fruit Waste. Int. Journal of Renewable Energy Development, 7(2), 101-109, doi.org/10.14710/ijred.7.2.101-109

P a g e | 104

Inoculum from fruit waste digester showed the highest hydrogen production activity on day 1 of fermentation (Fig. $1 \mathrm{~A}$ and $\mathrm{B}$ ) which the hydrogen production rate was reaching $559 \mathrm{~mL} / \mathrm{L}$.day. However, the production rate slows to $127 \mathrm{~mL} / \mathrm{L}$.day in the next time span and reaches the lowest point of $4 \mathrm{~mL} / \mathrm{L}$.day on the 5 th day of fermentation, before stopping on the 7 th day. The same trend observed for inoculum from cow dung and tofu waste digester. This phenomenon is influenced by the degree of acidity $(\mathrm{pH})$ of the fermentation medium (Fig. 1B). High hydrogen production rate indicates the optimal $\mathrm{pH}$ range, i.e. $\mathrm{FW}$ has an optimal $\mathrm{pH}$ of $5.59-7.10$, CD $5.63-7.04$ (283 mL/L.day) and TW 5.71 - 7.10 (224 mL/L.day). The $\mathrm{pH}$ values of all treatments correspond to the optimal $\mathrm{pH}$ range of hydrogen production, i.e., 5.5 to 7 (Van Ginkel et al., 2001; Fang and Liu, 2002; Khanal et al., 2004; Kawagoshi et al., 2005).

The hydrogen production rate is high along with a significant increase in the consumption of organic matter over the same time span of 0.74 to $1.09 \mathrm{~g} / \mathrm{L}(7-11 \%)$. Rotten fruits (such as melon waste used in this study) contain simpler and more easily degraded compounds (e.g., glucose, sucrose, fructose, and maltose). When $\mathrm{pH}$ conditions are optimal, acidogenic bacteria that produce hydrogen will transform simple sugars into other products to meet the needs of metabolism and cell growth. Such as acetate together with the formation of ATP as an energy source of cells and alcohol compounds are accompanied by regeneration of nicotinamide adenine dinucleotide $\left(\mathrm{NAD}^{+}\right)$ of the reduced form NADH (an essential molecule for continuing glycolysis) (Hallenbeck et al., 2012).

The hydrogen production rate is slower due to the decrease in acidity $(\mathrm{pH})$ of the fermentation media (Fig. 1B). Fermentative hydrogen production by acidogenic bacteria in conjunction with the formation of short chain fatty acids (volatile fatty acid/VFA) such as acetate, butyrate, and propionate (Mohanakrishna et al., 2010; Mohan et al., 2009). Inhibition of acetogenic bacteria and methanogenic (acetoclastic and hydrogenotrophic) activity led to the accumulation of VFA. Which resulted in a decrease in $\mathrm{pH}$ and the cessation of production of $\mathrm{H}_{2}$ as indicated by the slowing of hydrogen production rate (Lee et al., 2008; Zhang et al., 2012; Srikanth and Mohan, 2014). According to Van Ginkel et al. (2001) and Das et al. (2014), the inhibition process occurs when a non-polar undissociated acid penetrates into the cell and releasing protons that would destabilise the intracellular $\mathrm{pH}$ and cause denaturation of intracellular enzymes, including hydrogenases (essential hydrogen-producing enzyme). The $\mathrm{pH}$ of the media at the end of the fermentation process decreased to $4.63-4.78$ and hydrogen were not produced under this condition (Fig. 1B).
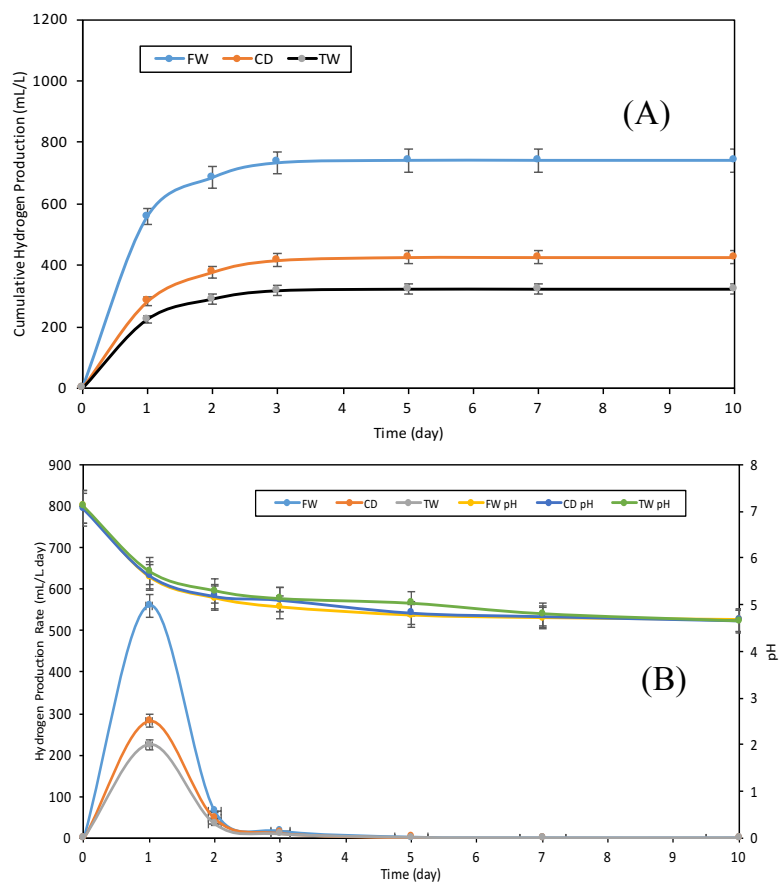

Figure 1. Cumulative production ${ }^{*}(\mathbf{A})$, hydrogen production rate and $\mathrm{pH}$ profile $(\mathbf{B})$ during dark fermentation of melon waste by inoculum from fruit waste digester (FW; $-\bullet ;-\bullet-)$ ), cow dung digester (CD; $\%$; $)$ and tofu waste digester (TW; $\mathscr{\varkappa}$; $\rightarrow$ ) $\left(37^{\circ} \mathrm{C}\right.$, start $\left.\mathrm{pH} 7\right) .{ }^{*}=$ gas volume at the standard conditions (1 atm, 25 $\mathrm{C}$ ); Error bar represented deviation standard of experimental data.

\subsection{Effect of the combination of inoculum from different anaerobic digester on hydrogen production from melon waste}

Inoculum from fruit waste (FW), cow dung (CD), and tofu waste (TW) digester are combined to see the effect of increased microbial diversity on hydrogen production performance. The low $\mathrm{pH}$ treatment ( $\mathrm{pH} 3 ; \pm 24$ hours) was able to limit the activity of the hydrogen users' bacteria, especially methanogens, which were active in a narrow $\mathrm{pH}$ range of $6.3-7.8$. It proved that no methane $(0 \%)$ was found to 7 days of hydrogen fermentation of melon waste, although the batch test performed at an initial $\mathrm{pH}$ of 7.05 \pm 0.05 . The test results showed that four combined treatments were capable of producing gases comprising $\mathrm{H}_{2}$ $(744-1,132 \mathrm{~mL} / \mathrm{L})$ and $\mathrm{CO}_{2}(586-792 \mathrm{~mL} / \mathrm{L})($ Table 2$)$.

Table 2.

Hydrogen production from melon waste in batch fermenter by combined inoculum from fruit waste digester (FW), cow dung digester (CD), tofu waste digester $(\mathrm{TW})\left(37^{\circ} \mathrm{C}\right.$, start $\mathrm{pH} 7$, volatile solid $\left.9.65 \mathrm{~g} / \mathrm{L}\right)$

\begin{tabular}{ccccccc|}
\hline Inc. & Final pH & $\begin{array}{c}\text { Total gas } \\
(\mathbf{m L} / \mathbf{L})\end{array}$ & $\begin{array}{c}\text { Total CO }_{2}{ }^{*} \\
(\mathbf{m L} / \mathbf{L})\end{array}$ & $\begin{array}{c}\text { Total H}_{2}{ }^{*} \\
(\mathbf{m L} / \mathbf{L})\end{array}$ & $\begin{array}{c}\text { Yield } \mathbf{H}_{2} \\
(\mathbf{m L} / \mathbf{g V S})\end{array}$ & $\begin{array}{c}\text { Yield } \mathbf{C O}_{2} \\
(\mathbf{m L} / \mathbf{g V S})\end{array}$ \\
\hline FW-CD & $4.71 \pm 0.01$ & $1,549 \pm 98^{\mathrm{a}}$ & $546 \pm 57$ & $1,003 \pm 41^{\mathrm{d}}$ & $288.30 \pm 0.66^{\mathrm{g}}$ & $156.75 \pm 10.21$ \\
CD-TW & $4.70 \pm 0.09$ & $1,387 \pm 69^{\mathrm{b}}$ & $643 \pm 30$ & $744 \pm 39^{\mathrm{e}}$ & $173.48 \pm 0.70^{\mathrm{h}}$ & $150.06 \pm 1.52$ \\
FW-TW & $4.65 \pm 0.06$ & $1,804 \pm 75^{\mathrm{c}}$ & $728 \pm 8$ & $1,077 \pm 677^{\mathrm{d}, \mathrm{f}}$ & $195.15 \pm 7.13^{\mathrm{i}}$ & $131.97 \pm 2.01$ \\
FW-CD-TW & $4.68 \pm 0.03$ & $1,902 \pm 70^{\mathrm{c}}$ & $770 \pm 31$ & $1,132 \pm 39^{\mathrm{f}}$ & $231.02 \pm 1.62^{\mathrm{j}}$ & $157.20 \pm 2.04$ \\
\hline
\end{tabular}

Legend: Inoculum combination of fruit waste and cow dung digester (FW-CD). Inoculum combination of cow dung and tofu waste digester (CD-TW). Inoculum combination of tofu waste and fruit waste digester (FW-TW). Inoculum combination of fruit waste, cow dung, and tofu waste digester (FW-CD-TW). * gas volume at the standard conditions $\left(1 \mathrm{~atm}, 25^{\circ} \mathrm{C}\right)$; different letter in the same column indicate significant difference statistically at the 0.05 level. 
Increased in diversity and interaction between microbial effects the hydrogen production performance. The combination of inoculum can increase the total hydrogen production (Table 2; Fig. 2) 1.74 to 3.50 times compared to the single inoculum. The combination of $\mathrm{FW}$ CD-TW produces the highest hydrogen compared to the combination of FW-CD, FW-TW, CD-TW, and its sole inoculum. These results indicate that the inoculum from different bio digesters able to adapt well to the environmental conditions and the new substrate after a combination process as a result of metabolic flexibility derived from the microbial diversity in the community.
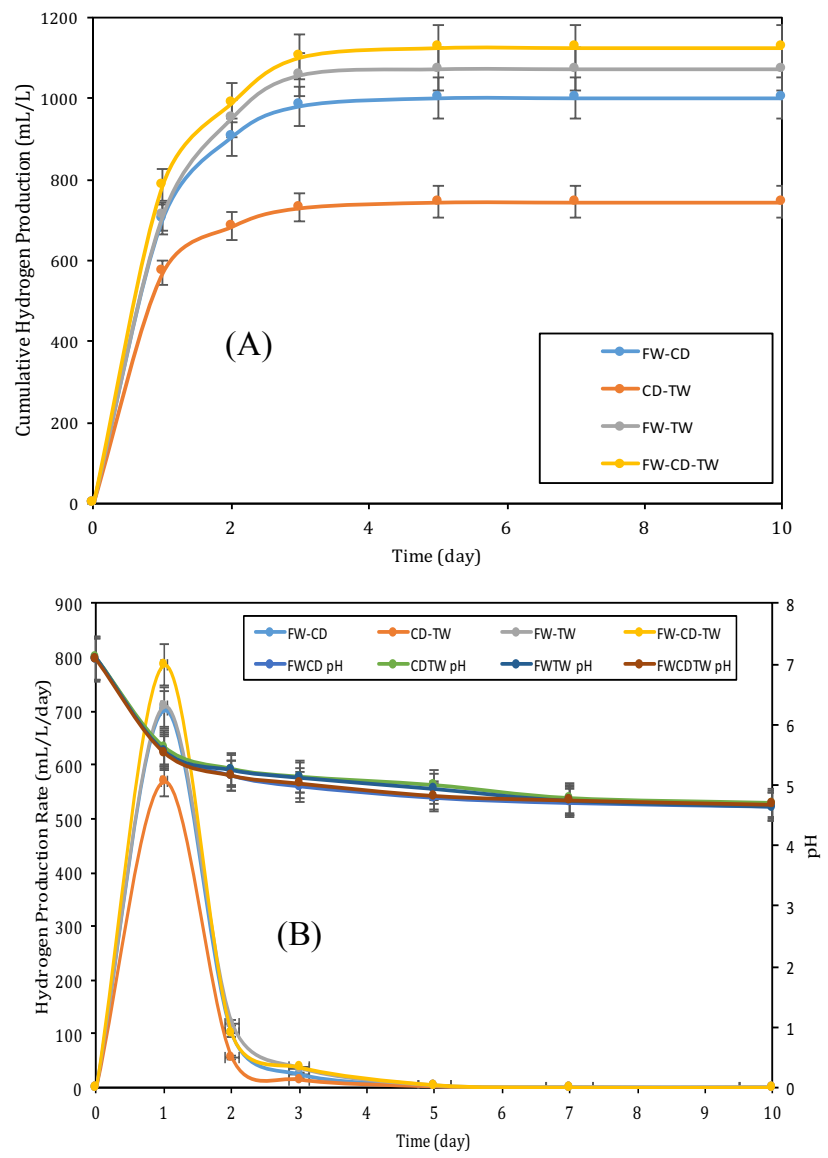

Figure 2. Cumulative production (A), hydrogen production rate and $\mathrm{pH}$ profile $(\mathbf{B})$ during dark fermentation of melon waste by combined inoculum from fruit waste digester (FW), cow dung digester (CD) and tofu waste digester (TW) $\left(37^{\circ} \mathrm{C}\right.$, start $\left.\mathrm{pH} 7\right) .{ }^{*}=$ gas volume at the standard conditions $\left(1 \mathrm{~atm}, 25^{\circ} \mathrm{C}\right)$; Error bar represented deviation standard of experimental data.

Microbial metabolic and physiological diversity means that there are a variety of pathways are utilised by different microbes to produce hydrogen (Hallenbeck and Benemann, 2012). Batch test results prove that the inoculum combination increases the hydrogen production capability. FW inoculum (129.74 mL/g; HPR 85.50 $\mathrm{mL} / \mathrm{L} . \mathrm{d})$ and TW inoculum $(92.39 \mathrm{~mL} / \mathrm{g} ; \mathrm{HPR} 64.50$ $\mathrm{mL} / \mathrm{L} . \mathrm{d})$ has higher yield and hydrogen production rate after combination FW-TW (173.48 mL/g; 148.70 mL/L.d).

Four inoculum combination tests had the highest rate of hydrogen production (Fig. 2B) on day 1 of fermentation, i.e., $570-786 \mathrm{~mL} / \mathrm{L}$.day. However, the production rate falls to $110-215 \mathrm{~mL} / \mathrm{L}$.day in the next time span and reaches a low of $7-11 \mathrm{~mL} / \mathrm{L}$.day on the 5 th day of fermentation, before stopping on the day-7. This phenomenon is similar to the batch test of single inoculum. Hydrogen production associated with VFA formation. The production and accumulation of acid metabolites gradually reduce the medium buffer capacity, so the $\mathrm{pH}$ of the medium decreases during the fermentation process (see Fig. 2B). The $\mathrm{pH}$ of inoculum and combination batch test media during fermentation showed a similar pattern. Hydrogen not produced by all tests in the $\mathrm{pH}$ range of $4.7-4.8$.

The batch test showed an increase in the yield and hydrogen production rate by four treatment combinations of inoculum up to 1.35 - 3.51 times of individual inoculums. Similarly, Sivagurunathan et al. (2014) using cow dung, sewage sludge and pig slurry show increase of 1.07 to 1.52 times. These results prove that increasing species diversity and microbial interactions due to combinations have a positive effect on improved hydrogen production performance.

\subsection{Metabolic end-products of hydrogen fermentation by} individual and combined inoculum

Fermentative hydrogen production by all treatments associated with the formation of volatile fatty acid (VFA) under anaerobic/acidogenic conditions. The pattern of VFA in mixed culture fermentation gives a general indication of the concerted metabolism of the community and affects the process performance directly ( $\mathrm{Ni}$ et al., 2014) as a result of the collective metabolism of mixed culture directly influences the hydrogen yield. The maximum theoretical yield of 4 mole and 2 mole of hydrogen could produce when acetic acid and butyric acid. Respectively are the sole end-product of fermentation. However, the yield significantly drops in case of mixed culture showing mixed-type fermentation due to the accumulation of other end-products like propionic, valeric, and caproic (Lee et al., 2008). As shown in Fig. 3, the VFA composition of single and combined inoculum's fermentation media constituted mainly butyrate $(\mathrm{HBu})$ and acetate (HAc). The range of HAc fraction in VFA was at $20-60 \%$. On the other hand, the scope of $\mathrm{HBu}$ fraction was at $6.39-18.74 \%$.

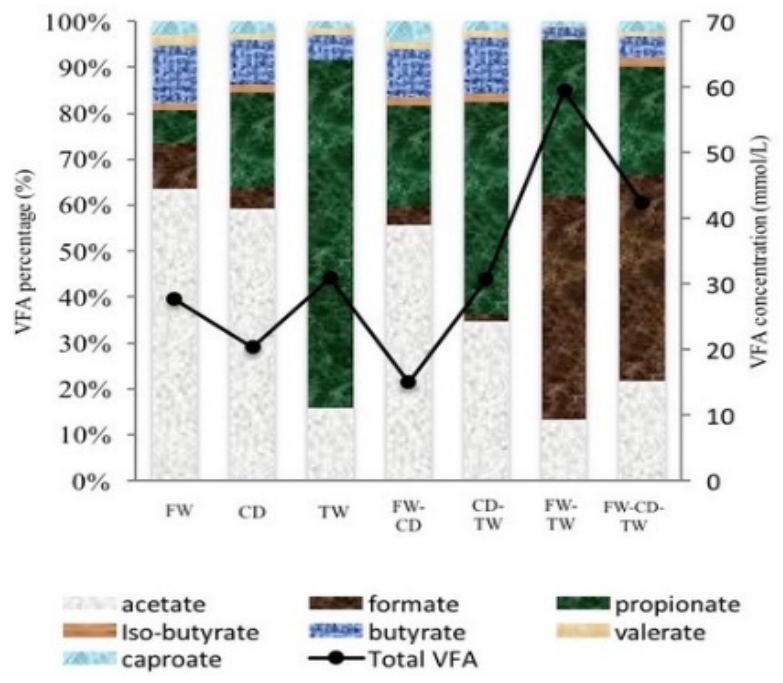

Figure 3. The percent fraction of VFA and total VFA concentration 
Hydrogen fermentation by individual inoculum from fruit waste digester produce total organic acids 1821.73 $\mathrm{mg} / \mathrm{L}$ consisting of acetic $1056.30 \mathrm{mg} / \mathrm{L}(57.98 \%)$, butyric $341.40 \mathrm{mg} / \mathrm{L}$ (18.74\%), formic $124.25 \mathrm{mg} / \mathrm{L}(6.8 \%)$, propionic $149.38 \mathrm{mg} / \mathrm{L}$ (8.20\%), valeric $64.30 \mathrm{mg} / \mathrm{L}(3.53 \%)$ and caproic $86.10 \mathrm{mg} / \mathrm{L}(4.73 \%)$. Variation of the final metabolite indicates the diversity of metabolic pathways used by acidogenic microflora in inoculum within seven days of the fermentation process. Pyruvate produced by EMP (Embden-Meyerhoff Pathway) dominantly converted to acetate because in the biochemical reactions of acetate formation occurs NADH regeneration and allow microbes to synthesise ATP (Saady, 2013). Butyrate formed when the hydrogen partial pressure increased $(>60 \mathrm{~Pa})$ to prevent the accumulation of NADH (Saady, 2013). Therefore, the acidogenic bacteria present in the FW has the best hydrogen production capability among CD and TW. Individual inoculum from fruit waste digester (FW) exploit acetate formation pathway for the oxidative decarboxylation of pyruvate and also produce hydrogen through NADH. However, the high production of propionic acid during the batch test of TW (23.38 mmole/L) compared to the FW and CD, each produces 2.02 and 4.21 mmole/L, causing the smaller volume of the hydrogen produced.

The FW-CD combination dominantly oxidises pyruvate to acetate, which is $499.63 \mathrm{mg} / \mathrm{L}(48.73 \%)$, due to the NADH regeneration and allow microbes to synthesise ATP (Saady, 2013). The CD-TW combination exploits propionate formation pathways during fermentation which the concentration of propionic reach $1049.20 \mathrm{mg} / \mathrm{L}$ $(47.71 \%)$. Bio reaction of propionate formation consume $\mathrm{H} 2$ as an electron donor in the form of reducing equivalents (NADH2; potential $\mathrm{H}_{2}$ ) (Fang and Liu, 2002) causing this treatment has the lowest hydrogen production capability than any other combination. The rank of hydrogen yield of the combination treatment: FWCD-TW (yield $231.02 \mathrm{~mL} / \mathrm{g}$; propionate $28.86 \%$ ) > FW-TW (yield $195.15 \mathrm{~mL} / \mathrm{g}$; propionate $42.22 \%$ ) > CD-TW (yield $173.48 \mathrm{~mL} / \mathrm{g}$; propionate $47.71 \%$ ). These results prove that higher production of propionic acid decrease hydrogen yield.

The results show that increased in diversity and interactions between microbes effect the yield and hydrogen production rate from the melon waste in batch fermenters. The FW-CD-TW combination shows the best hydrogen production capability compared to CD-TW, FWCD, CD-TW and single inoculum. Acetate and formic metabolic pathways are used dominantly by the two best combinations during the fermentation process. However, combinations involving the inoculum from the tofu waste digester exhibit a high propionate-forming activity thereby decreasing the hydrogen yield.

\subsection{Microbial community analysis}

DNA samples collected from all of the treatments at 0 , 1 , and 7 days of fermentation to see the change in the microbial community during the hydrogen fermentation process. This study found that carbon source replacement using melon waste affect the microbial abundance without any changes in the microbial community that involved in the fermentation. Denaturing Gradient Gel Electrophoresis (DGGE) analysis of the $16 \mathrm{~s}$ rDNA of single and combined inoculums showed that the microbial community was composed principally of five genera, i.e., Clostridium, Eubacterium, Vagococcus, Streptococcus, and Lactobacillus (Fig. 4 and Fig. 5). Interestingly, although FW and TW inoculum have same bacterial species richness and diversity index (lane 2 and 3 on DGGE profiles), FW produces higher hydrogen than TW. The only reason is the high production of propionic acid during fermentation of TW as mentioned before.

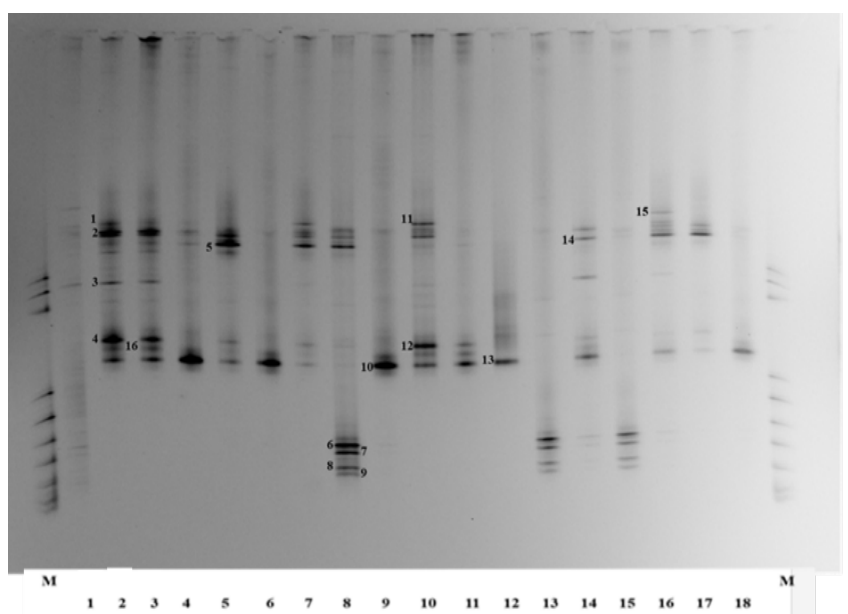

Figure 4. 16S rDNA profiles of $\mathrm{H}_{2}$ fermenting bacteria from combinations of different inoculum. Lanes 1-3: individual cultures from cow-dung (CD), fruit waste (FW), tofu waste (TW), respectively. Lane 4-18 were combined inoculum took on 0,1 and 7 day of fermentation. Lanes 4-6: fruit+cow-dung+tofu (FW-CDTW); 7-9: fruit+tofu (FW-TW); 10-12: fruit+cow-dung (FW-CD); 13-15: fruit (FW); 16-18: cow-dung+tofu (CD-TW). Bands 1-16 were sequenced for identification of bacterial species.

All bacterial species observed in all treatments usually found in $\mathrm{H}_{2}$ fermentation that using active sludge from wastewater as inoculum (Choin and Ahn, 2014; Kumar et al., 2015). The role of Vagococcus salmoninarium and Methylobacterium sp. in hydrogen fermentation was not well known yet. All bacteria in this study belong to Proteobacteria and Firmicutes phyla. Phylum proteobacteria have high ability to adapt and could break down large organic compounds into the simple compound. Phylum Firmicutes often plays a role in hydrogen fermentation (Jang et al., 2015). Inoculum source that used in this study had a source of the potential hydrogenproducing bacteria, i.e. Clostridium baratii and Clostridium perfringens, which always observed in day 1 of fermentation (peak of hydrogen production) in all treatments.

All single and combination of inoculums were not produce hydrogen 7 days of fermentation. It reflected from the Denaturing Gradient Gel Electrophoresis (DGGE) profiles and bacterial diversity index which showed Lactobacillus paracasei prominently detected during this time point. Noike et al. (2002) reported that Lactobacillus paracasei could inhibit the $\mathrm{H} 2$ fermentation by produced bacteriocin in a medium under $\mathrm{pH} 5$. 


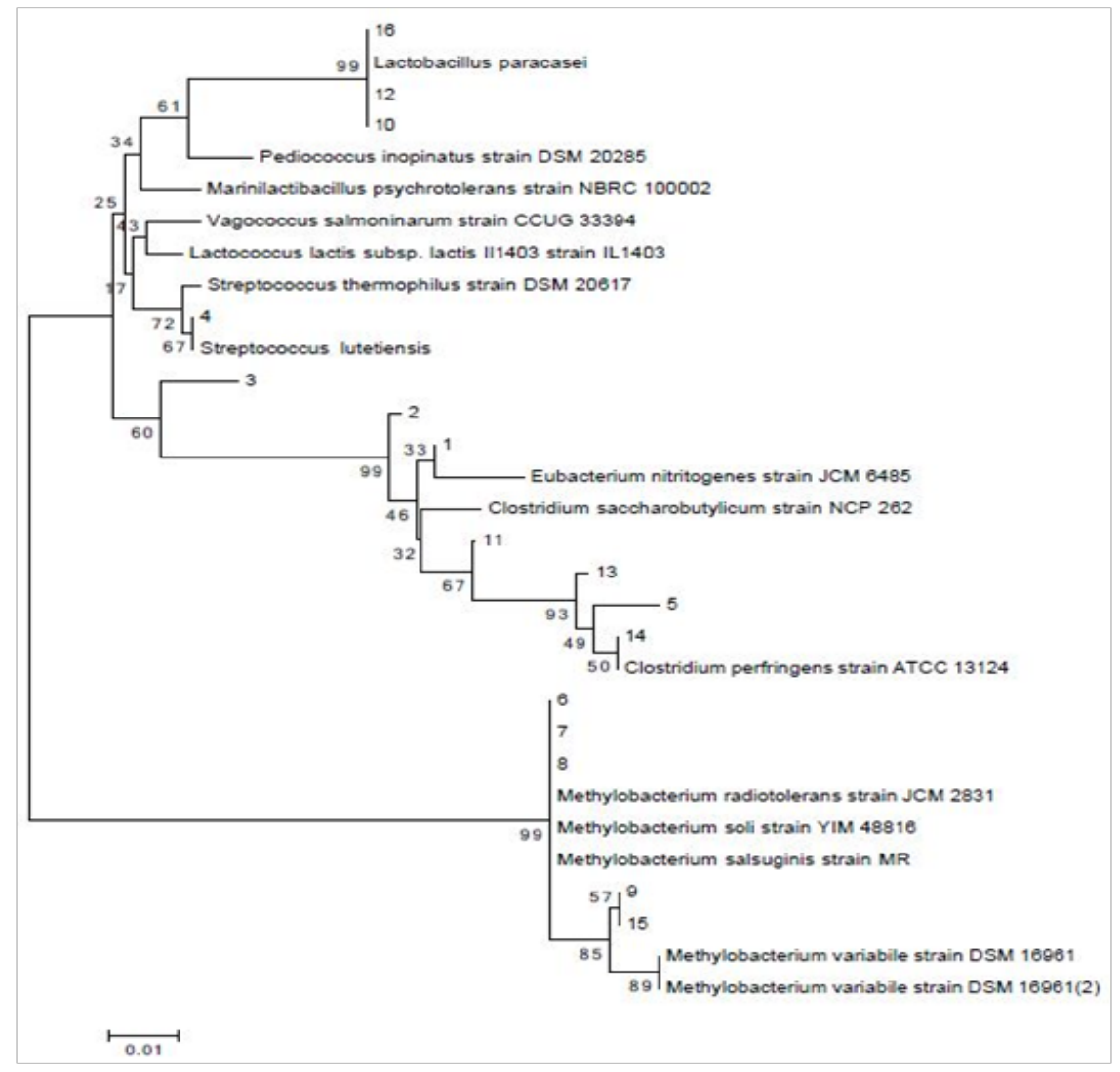

Figure 5. Phylogenetic trees analysis based on Denaturing Gradient Gel Electrophoresis (DGGE) profile. The branching pattern generated by the neighbour-joining method. The topology shown was obtained using 1000 bootstrap replication. The numbers at the nodes indicate the levels of bootstrap support percentage based on 1000 re-samplings.

\section{Conclusion}

This study demonstrated that increased in diversity and interaction between microbial effects the hydrogen production performance. The combination of inoculum can increase the total hydrogen production. Among the individual and combined inoculums, the highest cumulative hydrogen production of $743 \mathrm{~mL} / \mathrm{L}$ (yield 207.56 $\mathrm{mL} / \mathrm{g}$ ) and 1,132 $\mathrm{mL} / \mathrm{L}$ (yield $231.02 \mathrm{~mL} / \mathrm{g}$ ) shown by inoculum from fruit waste digester and the combination of inoculum from fruit waste-cow dung-tofu waste digester. Butyric, acetate, formic and propionic were the primary soluble metabolites produced by all the cultures, and the result proves that higher production of propionic acid can decrease hydrogen yield. Inoculum that used in this study had a source of the potential hydrogen-producing bacteria, i.e. Clostridium baratii and Clostridium perfringens. Experimental evidence suggests that hydrogen fermentation by inoculum combination could use as a strategy to improve systems for on-farm energy recovery from animal and plant waste to processing of food and municipal solid waste.

\section{Acknowledgments}

This study was supported by Indonesia Endowment Fund for Education (LPDP) to the first author and Short-Term Exchange Program in science and engineering at Tokyo University of Agriculture and Technology to the second author

\section{References}

Akutsu Y., Li Y., Tandukar M., Kubota K., et al. (2008). Effects of seed sludge on fermentative characteristics and microbial community structures in thermophilic hydrogen fermentation of starch. International Journal of Hydrogen Energy. 33, 6541-6548.

American Public Health Association, American Water Works Association, and Water Environment Federation, Standard methods for the examination of water and wastewater. 20th ed, APHA, AWWA, and WEF. Washington D.C. (USA): 1998.

Cai J.L., Wang G.C., Li Y.C., et al. (2009). Enrichment and hydrogen production by marine anaerobic hydrogenproducing Microflora. Chinese Science Bulletin. 54, 26562661.

Cahyari K., Syamsiah S., Sarto, et al. (2011). Hydrogen production from fruit waste through dark fermentation. 4th conference of Hydrogen and Fuel Cells in The Nordic Countries. Malmö. Sweden. 25-26 October 2011.

Chang S., Li J.Z., Liu F. (2011). Evaluation of different pretreatments methods for preparing hydrogen-producing seed inocula from waste activated sludge. Renewable Energy. $36,1517-1522$.

Choi J, Ahn Y. (2014). Characteristics of biohydrogen fermentation from various substrates. International Journal of Hydrogen Energy. 39, 3152-3159.

Choi J., Ahn Y. (2015). Biohydrogen fermentation from Sucrose and Piggery Waste with High Levels of Bicarbonate Alkalinity. Energies, 8, 1716-1729.

Das D., Veziroglu T.N. (2001). Hydrogen production by biological processes: a survey of literature. International Journal of Hydrogen Energy, 26, 13-28. 
Das D., Khanna N., Dasgupta C.N. (2014). Biohydrogen Production Fundamentals and Technology Advances. CRC Press Taylor \& Francis Group.

Díez B., Pedrós-Alió C., Marsh T.L., et al. (2001). Application of denaturing gradient gel electrophoresis (DGGE) to study the diversity of marine picoeukaryotic assemblages and comparison of DGGE with other molecular techniques. Application of Environmental Microbiology. 67, 2942-2951.

Fang H.H.P., Liu H. (2002). Effect of $\mathrm{pH}$ on hydrogen production from glucose by a mixed culture. Bioresource Technology. 82 , $87-93$.

Hallenbeck P.C., Abo-Hashesh M., Ghosh D. (2012). Review: Strategies for improving biological hydrogen production. Bioresource Technology. 110, 1-9.

Hallenbeck P.C., Benemann J.R. (2012). Biological hydrogen production; fundamentals and limiting processes. International Journal of Hydrogen Energy. 27, 1185-1193.

Han S.K., Shin H.S. (2004). Biohydrogen production by anaerobic fermentation of food waste. International Journal of Hydrogen Energy, 29, 569-577.

Hawkes F.R., Hussy I., Kyazze G., et al. (2007). Continuous dark fermentative hydrogen production by mesophilic microflora: Principles and progress. International Journal of Hydrogen Energy. 32, 172-184

Insam H., Franke-Whittle I., Goberna M. (2010). Microbes at Work: from waste to resources. Springer-Verlag Berlin Heidelberg.

Jang S., Kim D.H., Yun Y.M., et al. (2015). Hydrogen fermentation of food waste by alkali-shock pretreatment: Microbial community analysis and limitation of continuous operation. Bioresources and Technology. 186, 215-222.

Kapdan I.K., Kargi F. (2006). Bio-hydrogen production from waste materials. Enzyme and Microbial Technology. 38, 569582

Karthic P., Joseph P. (2012). Comparison and Limitations of Biohydrogen Process. Research Journal of Biotechnology, 7, $59-71$

Kawagoshi Y., Hino N., Fujimoto A., et al. (2005). Effect of inoculum conditioning on hydrogen fermentation and $\mathrm{pH}$ effect on bacterial community relevant to hydrogen production. Journal of Bioscience and Bioengineering. 100, 524-530.

Khanal S.K., Chen W.H., Li L., et al. (2004). Biological hydrogen production: effects of $\mathrm{pH}$ and intermediate products. International Journal of Hydrogen Energy. 29, 1123-1131.

Kumar G., Bakonyi P., S Periyasamy., et al. (2015). Lignocellulose biohydrogen: practical challenges and recent progress. Renewable and Sustainable Energy Rev., 44, 728-737.

Kumar G., Bakonyi P., Sivagurunathan P., et al. (2015). Enhanced biohydrogen production from industrial beverage wastewater using external nitrogen sources and bioaugmentation with facultative anaerobic strains. Journal of Bioscience and Bioengineering. 120, 155-160.

Lee H.S., Salerno M.B., Rittmann B.E (2008). Thermodynamic evaluation on $\mathrm{H} 2$ production in glucose fermentation. Environmental Science and Technology. 42, 2401-2407.

Li Z., Wang H., Tang Z., Wang X., et al. (2008). Effects of pH value and substrate concentration on hydrogen production from the anaerobic fermentation of glucose. International Journal of Hydrogen Energy. 13, 1-6.

Liu H., Wang G., Zhu D., et al. (2009). Enrichment of the hydrogen-producing microbial community from marine intertidal sludge by different pretreatment methods. International Journal of Hydrogen Energy. 34, 9696-9701.

Mohan, S.V. (2009). Harnessing of biohydrogen from wastewater treatment using mixed fermentative consortia: Process evaluation towards optimization. International Journal of Hydrogen Energy. 34, 7460-7474.

Mohan S.V., Babu M.L., Reddy M.V., et al. (2009). Harnessing of biohydrogen by acidogenic fermentation of Citrus limetta peelings: effect of extraction procedure and pretreatment of biocatalyst. International Journal of Hydrogen Energy. 34, 6149-6156.

Mohanakrishna G., Mohan S.V., Sarma P.N. (2010). Utilizing acid-rich effluents of fermentative hydrogen production process as substrate for harnessing bioelectricity: an integrative approach. International Journal of Hydrogen Energy. 35, 3440-3449.

Nath K., Das D. (2004). Improvement of Fermentative Hydrogen Production: Various Approaches. Appl. Microbiology and Biotechnology, 65, 520-529.

Ni B. J., Rittmann B.E., Yu H.Q. (2011). Soluble microbial products and their implications in mixed culture biotechnology. Trends Biotechnology. 29, 454-463.

Noike T., Takabatake H., Mizuno O., et al. (2002). Inhibition of hydrogen fermentation of organic wastes by lactic acid bacteria. International Journal of Hydrogen Energy. 13671371.

Pachapur V.L., Sarma S.J., Brar S.K., et al. (2015). Co-culture strategies for increased biohydrogen production. International Journal of Energy Research, 39, 1479-1504.

Pattra S., Sangyoka S., Boonmee M., et al. (2008). Bio-hydrogen production from the fermentation of sugarcane bagasse hydrolysate by Clostridium butyricum. International Journal of Hydrogen Energy. 33, 5256-5265.

Reith J.H., Wijffels R.H., Barten H. (2003). Bio-methane and biohydrogen - status and perspective of biological methane and hydrogen production. Dutch Biological Hydrogen Foundation: The Hague.

Ren N.Q., Guo W.Q., Wang X.J., et al. (2008). Effects of different pretreatment methods on fermentation types and dominant bacteria for hydrogen production. International Journal of Hydrogen Energy. 33, 4318-4324.

Ruggeri B., Tommasi T. (2012). Efficiency, and efficacy of pretreatment and bioreaction for bio-H2 energy production from organic waste. International Journal of Hydrogen Energy. 37, 6491-6502.

Ruknongsaeng P., Reungsang A., Moonamart S., et al. (2005). Influent of nitrogen, acetate, and propionate on hydrogen production from pineapple waste extract by Rhodospirillum rubrum. Journal of Water Environment. Technol. 13, 93-117.

Saady, N.M.C. (2013). Homoacetogenesis during hydrogen production by mixed cultures dark fermentation: Unresolved challenge. International Journal of Hydrogen Energy. 38, 13172-13191.

Sivagurunathan P., Sen B., Lin C.Y. (2014). Batch fermentative hydrogen production by enriched mixed culture: Combination strategy and their microbial composition. Journal of Bioscience Bioengineering. 117, 222-228.

Sivagurunathan P., et al. (2016). A critical review on issues and overcoming strategies for the enhancement of dark fermentative hydrogen production in continuous systems. International Journal of Hydrogen Energy, http://dx.doi.org/10.1016/j.ijhydene.2015.12.081

Sivagurunathan P., Anburajan P., Kumar G., et al. (2016). Improvement of hydrogen fermentation of galactose by combined inoculation strategy. J. Biosci. Bioeng. XX, 1-5. http://dx.doi.org/10.1016/j.jbiosc.2016.10.006

Srikanth S., Mohan S.V. (2014). Regulating feedback inhibition caused by the accumulated acid intermediates during acidogenic hydrogen production through feed replacement. International Journal of Hydrogen Energy. 39, 10028-10040.

Sun W., Liu J., Xu H., et al. (2015). l-Lactic acid fermentation by Enterococcus faecium: a new isolate from bovine rumen. Biotechnology Letter. 37, 1379-1383.

Tien H.M., Le K.A., Tran A. T., et al. (2016). Effect of fermentation condition on biohydrogen production from cassava starch by anaerobic mixed cultures. The 3rd AUN/SEED-NET Regional Conference on Energy Engineering and the 7th International Conference on Thermofluids (RCEnE/THERMOFLUID 2015). doi: 10.1063/1.4949310. 
Van Ginkel S., Sung S.W., Lay J.J. (2001). Biohydrogen production as a function of $\mathrm{pH}$ and substrate concentration. Environmental Science and Technology. 35, 4726-4730.

Yokoi H., Saitsu A., Uchida H., et al. (2001). Microbial Hydrogen Production from Sweet Potato Starch Residue. Journal of Bioscience Bioengineering, 91, 58-63.
Zhang L., Li J., Ban Q., et al. (2012). Metabolic pathways of hydrogen production in fermentative acidogenic microflora. Journal of Microbiology and Biotechnology. 22, 668-67 